\title{
Strengthening Small And Medium Enterprises (SMEs) Through Sociopreneurship- Based Communities In Technology Sustainability
}

\author{
Martin Purnama Chandra \\ Universitas Sangga Buana, Bandung \\ martin.chandra@usbypkp.ac.id
}

\begin{abstract}
The low percentage of digitization implementation is the biggest challenge in growing digital technology among Small and Medium Enterprises (SMEs). The limited level of education has implications for how to learn and understand everything of digitalization, so support is needed in optimizing the use of technology in Sociopreneurship-based communities. This research aims to explain the strengthening of SMEs through Sociopreneurship-based communities to achieve technology sustainability. The method used is descriptive qualitative with primary and secondary data sources. The result of this research is that the community-based Sociopreneurship plays a role in accommodating the private and government sectors to overcome the barriers to using technology that is often faced by SMEs. With the idea that technology can add value to this sector, the existence of a community will lead to an analysis of how technology changes SMEs in running their business and creates a competitive advantage. They also collaborate with universities for implementation, experimentation, and discoveries on the practice of using technology in the SMEs sector, which will be poured into the research, which will then be evaluated and applied. This research concludes that Sociopreneurshipbased communities are an important factor in strengthening SMEs in achieving technology sustainability. Sociopreneurship between various related parties provides support in the use of digital technology to create competitiveness and competitive advantage as an intangible innovation capability.
\end{abstract}

Keywords: communities; enterprises; smes; sociopreneurship; technology

\begin{abstract}
Abstrak
Rendahnya persentase implementasi digitalisasi menjadi tantangan terbesar dalam menumbuhkan teknologi digital di kalangan Usaha Kecil dan Menengah (UKM). Tingkat pendidikan yang terbatas berimplikasi pada cara mempelajari dan memahami segala sesuatu tentang digitalisasi, sehingga diperlukan dukungan dalam optimalisasi pemanfaatan teknologi pada komunitas berbasis Sociopreneurship. Penelitian ini bertujuan untuk menjelaskan penguatan UKM melalui komunitas berbasis Sociopreneurship untuk mencapai keberlanjutan teknologi. Metode yang digunakan adalah deskriptif kualitatif dengan sumber data primer dan sekunder. Hasil dari penelitian ini adalah Sociopreneurship berbasis masyarakat berperan dalam mengakomodir sektor swasta dan pemerintah dengan tujuan untuk mengatasi hambatan penggunaan teknologi yang sering dihadapi oleh UKM. Dengan pemikiran bahwa teknologi dapat memberikan nilai tambah pada sektor ini, keberadaan komunitas akan membawa pada analisis tentang bagaimana teknologi mengubah UKM dalam menjalankan bisnisnya dan menciptakan keunggulan kompetitif. Mereka juga bekerja sama dengan perguruan tinggi untuk implementasi, eksperimen, dan penemuan-penemuan baru tentang praktik pemanfaatan teknologi di sektor UKM, yang akan dituangkan ke dalam penelitian, yang kemudian akan dievaluasi dan diterapkan. Penelitian ini menyimpulkan bahwa komunitas berbasis Sociopreneurship merupakan faktor penting dalam memperkuat UKM dalam mencapai keberlanjutan teknologi. Sociopreneurship antara berbagai pihak terkait memberikan dukungan dalam pemanfaatan teknologi digital guna menciptakan daya saing dan keunggulan kompetitif sebagai kapabilitas inovasi yang tidak berwujud.
\end{abstract}

Kata kunci: komunitas; perusahaan; sociopreneurship; teknologi; ukm

\section{INTRODUCTION}

The emergence of e-commerce for SMEs in Indonesia is considered a breath of fresh air, but carrying out digitalization efforts is not easy. There are $16.33 \%$ of SMEs connected to online marketplaces and digital markets. Based on data from the Ministry of Cooperatives and Small and Medium Enterprises (SMEs), the percentage has only reached $13 \%$. From this figure, it is understood that around $87 \%$ of business actors have not 1 | JURNAL DIMMENSI | Vol.2 | No.1 | 2022 
succeeded in digitizing their businesses. This condition is in stark contrast to Indonesia's efforts which are now encouraging people's adaptation to the industrial revolution 4.0 (Rachmawati, 2020).

The condition of the low percentage of digitization by SMEs has become more complex with the New Normal policy. The biggest challenge is how to grow digital technology among SMEs. Cause, technology makes it easy for SMEs to carry out business processes when the New Normal policy is implemented as the beginning of Indonesia's recovery. Therefore, the existence of this policy brings urgency in technology and information literacy for SMEs to adapt (Rahmana, 2021). The adaptation referred to refers to shifting both entrepreneur behavior and economic activity (Maelatusaadah et al, 2018). Its goal is for the SMEs sector can survive and be sustainable despite changes in activity, such as a phenomenon that was felt when the Corona Virus Disease (Covid-19) hit and shook the lives of all countries globally.

Changes in activities that were initially carried out directly and carried out without any media are now encouraging the evolution of businesses to be online. SMEs are required to learn and understand all things based on digitization, such as social media and information sharing through existing technology. Unfortunately, not all SMEs can quickly learn technology as well as understand the benefits and functions of technology itself for their business. This is evidenced by the fact that the education level of SMEs is still low. As an example of the existing data, it was found that from 140 respondents, SMEs in Surabaya had an educational background consisting of 21 elementary schools, 17 junior high schools, and 72 high school students. So, the data concludes that $73 \%$ of SMEs in Surabaya have an educational background below a bachelor's degree (Nainggolan, 2016). The condition of the educational background will affect the mindset, experience, access to information, and level of analysis. The same is true when it comes to efforts to adopt digital technology by SMEs.

Furthermore, the development of digital technology goes hand in hand with the phenomenon of the demographic bonus in Indonesia, which is predicted to occur in 2030-2045. It means the number of productive age is more than the non-productive age. This goes linearly with opportunities for young people to be creative in the SMEs sector. In other words, the number of SMEs in Indonesia will increase (Ardiana et al, 2010).

SMEs are one of the vital sectors that contribute greatly to encouraging national economic growth and sustainable development in a country. So, the existence of SMEs can no longer be ignored and a new breakout is needed to empower the SMEs themselves. It means that support at various levels of society is needed to revive the potential of Indonesian SMEs by optimizing the use of technology and information.

The question support refers to the concept of Sociopreneurship. The emergence of this concept has been converging on the establishment of communities that consist of sociopreneurs with backgrounds in various fields of science, such as technology, business, public policy, communication, and other related fields of science. Some of these fields will support each other in optimizing the benefits of technology sharing through the collaboration of knowledge and sociopreneurs experience.

Technology sharing can improve the competitiveness of SMEs both mentally, market access, administrative efficiency, and the business itself in a modern way (Bauer et al, 2010). These results can be achieved through measurable and strategic work programs created by sociopreneurs to be applied in the SMEs sector. Not only that, but the presence of sociopreneurs in a community also helps SMEs in overcoming various social problems.

From the description above, this research aims to explain the strengthening of SMEs through Sociopreneurship-based communities to achieve sustainable technology. From this aim, it will draw an analysis of whether the role of sociopreneurs who are members of a community to improve the skills, knowledge, and experience of SMEs in adapting digital technology is necessary or not. This will determine whether the Indonesian SMEs sector can compete and expand market access both on a national and international scale.

This research identifies how to strengthen SMEs through Sociopreneurship-based communities in supporting the adaptation of digital technology. From the identification of this problem, the researcher tries to analyze the potential of sharing knowledge, experience, and the ability to use 2 | JURNAL DIMMENSI | Vol.2 | No.1 | 2022 
technology that is sheltered by the Sociopreneurship-based communities to achieve operational efficiency and competitive advantage for SMEs. The benefit of this research is to encourage SMEs to adopt digital technology effectively, efficiently, and intelligently.

\section{LITERATURE REVIEW}

In analyzing the object of research, the researcher uses the concept of Sociopreneurship with community concentration. Sociopreneurship is social-based entrepreneurship that works for the benefit of the community and does not focus on profit-oriented. Sociopreneurs act as agents of change for society through new perspectives, system improvements, the economy, and finding solutions through new approaches to improve people's lives, especially the lower middle class.

Sociopreneurship combines two goals, namely to gain profit and provide a good social impact for the community. The presence of sociopreneurs will provide changes that go hand in hand with the discovery of new solutions to overcome social problems that occur. The business expansion carried out by sociopreneurs is solely for the sake of helping the community. Supported by in recent times sociopreneurs can overcome social problems faced by the community, such as education problems, health problems, unemployment, and poverty. Sociopreneurship effectiveness is measured by the level of reduced social problems.

Sociopreneurship is defined as an innovative activity that creates social value. Sociopreneurship is also seen from its main focus on social missions to its main orientation on the commercial side and social goals. Sociopreneurship doesn't have to be philanthropic (generous) or commercial to strike a productive balance (Austin et al, 2012).

Drayton formulated Sociopreneurship to overcome social problems through steps, namely influencing people to make changes. Changing the system is not an easy thing because it must involve all related elements. People who are one of these elements must be made aware of the problems that exist because it cannot be ascertained that they are able problems properly and systematically. Before heading to the search for a solution to the problem, it is necessary to first know the source of the problem. From this, it will lead to a change at the final stage. This change needs to be made as a correction and part of the evaluation of actions or decisions that were not right in the past.

Sociopreneurship actors can be individuals, organizations that are proactive in alleviating various social problems (Tan et al, 2005). There are several forms of social salesperson organization:

a.Communities based organization

This organization concentrates on addressing the problems of certain community groups. For example, non-formal education for the street children community, training for groups of former drug addicts, organizations for the guidance of the blind, farmer groups, farmer groups, and so on. The funding for this organization usually comes from volunteers who raise funds and donors.

\section{b.Socially responsible enterprises}

Socially responsible enterprises can be companies that are legal entities and then do business for profit. The profits will be allocated for social purposes. The establishment of this organization can also be in the form of two companies at once, where one company is commercial and the another is social. Commercial company profits will help fund and finance the operations of social activities.

c. Socio-economic or dualistic enterprises

Socio-economic or dualistic enterprises in the form of commercial enterprises that are established to solve social problems professionally. The more Socioeconomic or dualistic enterprises, the hope to reduce and overcome various social problems is getting bigger. For example, companies that hire people with disabilities, recycling companies, and companies that provide funding.

\section{Previous Studies}

There are several previous studies are to support the object of research, including the first, Information Technology Interventions for Growth and Competitiveness in Micro-Enterprises (Qureshil Et al, 2009).

This research explains that the use of computers affects the productivity of companies and expands networks in the industrial sector. A survey was also conducted of micro, small and medium-sized manufacturing companies in the Boston area and found that the majority of micro-enterprises used

3 | JURNAL DIMMENSI | Vol.2 | No.1 | 2022 
simple technologies, such as basic email, and simple software packages compared to more complex technologies used by mid-sized companies.

The survey results illustrate that micro-enterprises do not understand most of the benefits of technology to improve business performance. This research illustrates how important and necessary the adoption of technology is in improving business performance regardless of the level of the business.

Business performance can be seen from the extent to which an entrepreneur can bring up technology adoption as an intangible aspect of innovation capability. This is in line with the second previous study, namely Intangible Aspects of Innovation Capability In SMEs: Impacts Of Size And Industry (Saunila et al, 2014).

This research tries to test whether the size of the company or industry has a significant impact on the intangible aspects of the innovation ability of SMEs. The results illustrate that firm size does not explain the level of innovation ability. This result is important because the previous research carried out found that small firms are more resourceconstrained.

Unfortunately, these characteristics do not apply to innovation capability and the difference between the intangible aspects of innovation capability in SMEs. External knowledge is also an important source of innovation that is carried out through interaction with external sources. These interactions provide information that the company does not have. The company's ability to collaborate externally is the key to the company's innovative success.

Significant differences in the intangible aspects oriented to the industries and services studied. No difference was found except for the development of knowledge. This research contributes to the literature by showing that predictors other than industry should turn capabilities into successful innovations that lead to knowledge building such as an understanding of the use of technology. The research also highlights that knowledge development is a necessity in working well-being. Therefore, knowledge development needs to be applied through interaction with external parties, namely Sociopreneurship-based communities.
Third, a research entitled Technosociopreneur, New Model of SMEs in the New Normal Era. This research explains the entrepreneurship business model for SMEs and is sustainable in the New Normal era (Silvatika, 2020). The challenges of SMEs in the New Normal era are the right adaptation momentum towards changing entrepreneurial motives by using digital technology or known as Technosociopreneur. Technosociopreneur development requires a synergy between academics, business actors, communities, government, and the media to support the social entrepreneurship ecosystem consisting of policy actors, capital owners, parties with moral support as well as market and infrastructure access, as well as various parties that provide differentiating factors for location. or geographic.

From the three previous studies, the researcher tries to take the substance and the results as a case study that leads to the goal of sustainable technology. The researcher tries to summarize alternative solutions from each of the three previous research problem formulations that refer to the concept of Sociopreneurship.

Sociopreneurship will be applied in the form of communities that help SMEs in adopting digital technology. After joining the communities, SMEs will interact to transfer knowledge, information, experience, and digital technology skills as an intangible aspect to increase innovation capability. The communities also act as an arm to touch-related parties, such as education, government, and investors to optimize the synergy of the Sociopreneurship ecosystem. The ultimate goal is to create Technosociopreneurs that can use technology as the key to managing their products and networks.

\section{METHODOLOGY}

This research uses descriptive qualitative research methods with data study techniques and case studies as the basis for writing. This method was chosen because qualitative research can be carried out by researchers to describe the object of research as a sociopreneurship phenomenon. Following the problems in this research will highlight the strengthening of SMEs Sociopreneurship-based communities in achieving sustainable technology goals. This research uses primary data sources derived from previous research, scientific articles or 
proceedings, and secondary data such as books and the internet.

\section{RESULT AND DISCUSSION}

The presence of a pandemic has a direct negative impact on SMEs. In 2019, SMEs only contributed $65 \%$ of the Gross Domestic Product (GDP) or around IDR 2,394.5 trillion. SMEs from various business sectors do not operate optimally. Only $5.9 \%$ of SMEs were able to survive the pandemic. On the other hand, there were $82.9 \%$ of business actors were negatively affected with $63.9 \%$ experiencing a decrease in turnover of more than $30 \%$ (Sinuraya, 2020). SMEs need a solution to keep their business alive and survive any changes.

The solution in question refers to the adaptation of digital technology considering that the pattern of people's lives is transforming towards digital. Lifestyles at all economic levels, such as meeting primary needs, have shifted towards digital with intending to reducetiesrly outside the home. Changes in consumption patterns of goods and services from offline to online have succeeded in increasing traffic using digital technology by around $15-20 \%$, as well as increasing the use of elearning, e-commerce, increasing demand for delivery, digital literacy, and the need for medical devices (Wirapraja et al, 2018).

The use of digital technology in the SMEs sector can play an important role in increasing productivity and sales through access to new markets and administrative efficiencies. The role of digital technology intermediaries can provide the information needed by markets, customers, and suppliers. In research of 1000 small businesses in the United States, it was found that businesses are ready to adopt technology through a website presence. The pressures of engaging competition and promoting customer service far outweigh the barriers to creating a website (Riemenschneider et al, 2003).

For the SMEs sector to get any benefits from technology and reach a level where they can compete, it is necessary to remove some of the barriers that are holding them back. A number of these obstacles have been identified, including:

1. Affordability, where they operate with very limited budgets and do not have sufficient capital to allocate to technology use.
2. Awareness about technology. Most SMEs do not have technical skills and are not aware of technological capabilities. As a result, the power of technology is not utilized for business development.

3. Infrastructure as a core requirement of all forms of technology implementation is inadequate so that it becomes a major barrier to technology adoption and use.

4. Social, private, and government sectors. Any of the three communities play an important role in infrastructure development to promote the increased use of technology.

5. Management capacity to incorporate technology into the SMEs environment is low.

From the five obstacles above, the researcher highlights the fourth point where the social sector can be represented by a Sociopreneurship-based community that can accommodate the private and government sectors. The role played is to overcome other obstacles that have been clear in points 1,2 , 3 , and 5. In this way, it will form a Sociopreneurship ecosystem that is synergistic between various related parties with the support provided, such as policy actors, investors, parties who provide moral support as well as access to markets and infrastructure, as well as various parties who can provide differentiating factors of location or geography.

Sociopreneurs will address one by one the problems faced by SMEs, such as geographic challenges. The remote location results in low access to education, poor business skills, poverty, and lack of transportation. These limitations will place Sociopreneurship-based communities to take strategic steps from technology applications to generate strategic impacts from the development of current technology applications. The communities will help the extent to which management can be used for consideration of appropriate alternatives in the pursuit of increasing competitiveness.

By taking the idea that technology can add value to the SMEs sector, the existence of communities will lead to a transfer of discussion through an analysis of how advances in information technology have changed SMEs to run their business and create a competitive advantage.

Sociopreneurship-based communities narrow the focus of SMEs to emphasize customer relationships and show how information systems technology can 
improve customer relationships. Not only that, the communities as a forum for SMEs will also measure the extent to which the application of the technology forms a competitive advantage that refers to constructs on five main dimensions.

1. The efficiency of technology application for SMEs to offer lower prices than other competitors.

2. The functionality of the technology application provides the user with the required functionality.

3. Impact of applying technology.

4. Preemptiveness, namely the virtue of early penetration with the successful application of technology to the market.

5. The synergy of technology applications that are closely integrated with business objectives, and strategies.

The market changes so fast, with the joining of SMEs in the community, Sociopreneurs combine market understanding with technology to create potential and competitive opportunities through existing resources. This collaboration will print SMEs into Technosociopreneurs and then use them to attract several stakeholders, such as Banking, and Digital Financial Innovation Actors (eg Growpal, Tanifund, Crowde, and Amartha).

Likewise, with community access to the government institutional environment. Government support related to the Sociopreneurs program and technology is also contained in the 2020-2024 RPJMN, namely the Entrepreneurship Strengthening Program, SMEs, and Cooperatives. Implementation of collaborative partnerships with stakeholders bridged by Sociopreneurship-based communities is a solution to encourage the improvement of the welfare of SMEs

Furthermore, the communities also play their role by accessing universities. Universities that follow the curriculum set by the Ministry of Research, Technology and Higher Education must have entrepreneurship programs that are realized by the existence of Entrepreneurship courses and activities. However, the contents of these lectures and activities have not adequately directed the practitioners of Entrepreneurship to the development of digital technology. Therefore, the Sociopreneurship-based community collaborates with the university for the entrepreneurship development of students, and SMEs themselves. Implementation, experiments, and discoveries obtained in the practice of using technology in the SMEs sector will be poured into scientific research based on academic knowledge in the world of higher education which will then be evaluated and applied for the benefit of SMEs (Chuop, 2016).

That way, the communities will bridge the SMEs through the support of academic knowledge capabilities played by the universities. This is interesting because SMEs work alone to generate profits through business processes. This collaboration can be interpreted as a process of creative and innovative abilities carried out by applying and utilizing science to carry out activities that provide added value for science itself and society (Handrimurtjahjo, 2013). In Indonesia, Sociopreneurship-based communities collaboration with universities to strengthen SMEs in achieving technology sustainability has been implemented. Researchers take an example, namely the Rich Club as a Sociopreneurhip-based community supported by academics (including by researchers) in empowering these SMEs.

\section{CONCLUSION}

From the results and discussion above, the researcher concludes that the Sociopreneurshipbased communities are an important factor in strengthening SMEs in achieving technology sustainability. The communities will take on a role that can accommodate the private and government sectors. That way, other obstacles that have been mein points $1,2,3$, and 5 in the discussion can be overcome. As a result, the communities can optimize the synergy of the Sociopreneurship ecosystem between various related parties to provide support to SMEs in the use of digital technology to create competitiveness and competitive advantage as an intangible innovation capability. The existence of a Sociopreneurshipbased community that houses SMEs, proves that not only business actors from the upper-middle-class need to use digital technology for their business, but also small and micro-level businesses. SMEs need to be embraced and fostered not only in a practical way but also by involving academic knowledge represented by universities' involvement.

The presentation of this research analysis illustrates that strengthening SMEs through Sociopreneurship-based communities can build opportunities in technology sustainability. That way, strengthening SMEs can run linearly with community adaptation efforts to the industrial revolution 4.0. Moreover, the phenomenon of 6 | JURNAL DIMMENSI | Vol.2 | No.1| 2022 
Sociopreneurship has developed with intending to intend overcome various social problems.

Hope to be better in technology sustainability, Indonesia can slowly support every activity and program carried out by sociopreneurs considering the impact given to the presence of Sociopreneurship-based communities is very influential on strengthening SMEs in the use of digital technology. It can be taken into consideration and become a reference for the government regarding things that need to be improved, especially in terms of policies in the field of Sociopreneurship to support the SMEs sector which still needs to be overhauled. In the potential of the communities, they still face various challenges to maximize and support SMEs through coordination across ministries and state institutions, infrastructure, and funds

\section{REFERENCES}

\section{Journal:}

Ardiana, I. D. K. R. and I. A. Brahmayanti. (2010). Kompetensi SDM UKM dan Pengaruhnya Terhadap Kinerja UKM di Surabaya. J. Manaj. dan Kewirausahaan, vol. 12, no. 1, pp. 42-55.

Austin et al. (2012). Social and commercial entrepreneurship: same, different, or both?. Rev. Adm., vol. 47, no. 3, pp. 370-384.

Bauer, S. and J. Flagg. (2010). Technology Transfer and Technology Transfer Intermediaries. Assist. Technol. Outcomes Benefits, vol. 6, no. 1, pp. 129-150.

Handrimurtjahjo, A. D. (2013). Model Pembelajaran Kewirausahaan Di Perguruan Tinggi. Jurnal Universitas Paramadina, vol. 10, no. 2, pp. 729-755.

Maelatusaadah, L. M., A. Rahayu, and D. H. Utama. (2018). Gambaran Switching Cost Dan Customer Switching Behavior Pada Pelanggan Mnc Play Di Bandung. J. Bus. Manag. Educ., vol. 3, no. 3, pp. 25-33.

Nainggolan, R. (2016). Gender, Tingkat Pendidikan Dan Lama Usaha Sebagai Determinan Penghasilan UMKM Kota Surabaya. Kinerja, vol. 20, no. 1, p. 1.

Qureshil, S. Et al. (2009). Information technology interventions for growth and competitiveness in micro-enterprises. Int. J. Enterp. Inf. Syst., vol. 5, no. 2, pp. 72-95.

Rahmana, A et al. (2021). Pendampingan Strategi Pemasaran Digital Produk Makanan Dalam Menjalankan Bisnis Di Era New Normal Di Kota Bandung. Al-Khidmat, vol. 4, no. 1, pp. 49-57.

Riemenschneider, C. H. (2003). Understanding IT Adoption Decisions in Small Business: Integrating Current Theories. Inf. Management. Journal, vol. 40, no. 4, pp. 269-285.

Saunila, M. and J. Ukko. (2014). Intangible aspects of innovation capability in SMEs: Impacts of size and industry. J. Eng. Technol. Manag. - JET-M, vol. 33, no. October 2017, pp. 32-46.

Tan et al. (2005). Defining the 'Social' in 'Social Entrepreneurship': Altruism and Entrepreneurship. Int. Entrep. Manag. J., vol. 1, no. 3, pp. 353-365.

Wirapraja, A and H. Aribowo. (2018). Pemanfaatan E-Commerce Sebagai Solusi Inovasi Dalam Menjaga Sustainability Bisnis. Teknika, vol. 7, no. 1, pp. 66-72.

\section{Proceeding:}

Silvatika, B. A. (2020). Technosociopreneur, New Model UMKM di Era New Normal. Pros. Semin. Stiami, vol. 7, no. 2, pp. 29-35

Sinuraya J. (2020). Potensi UMKM Dalam Menyangga Perekonomian Kerakyatan di Masa Pandemi Covid-19: Sebuah Kajian Literatur. Pros. Semin. Akad. Tah. Ilmu Ekon. dan Stud. Pembang. 2020, p. 160.

\section{Internet Site:}

Rachmawati, A. R. (2020). Masih Rendah, Baru 16,33 Persen UMKM yang Adopsi Teknologi Digital. Accessed on: https://www.pikiranrakyat.com/ekonomi/p r-01583158/masihrendah-baru-1633-perse n-umkm-yang-adopsiteknologi-digital.

\section{Thesis:}

Chuop. (2016). Knowledge Management in the Internationalization of SMEs: From the Practices to the Challenges. Thesis Master Sci. Management. 